\title{
Occupational Stress and Job Satisfaction among Police and Teacher
}

\author{
Luhar Urmilaben Manubhai ${ }^{1}$, Dr. Krishnaben Vaghela ${ }^{2}$ \\ ${ }^{1}$ Research Scholar in Psychology, Saurashtra University, Rajkot, Gujarat-India \\ ${ }^{2}$ Associate Professor, Yogiji Maharaj Mahavidyalaya Mahila Arts and Commerce College Dhari, Gujarat - India
}

\begin{abstract}
The main purpose of this research was to find out the study of Occupational Stress and Job Satisfaction among Police and Teacher. For these Total 60 Police and Teacher (30 Police 30 Teacher) were taken as a sample. The research tool for Occupational Stress was measured by psychologist A.K. Shrivastav \&Singh. While the tools for Job Satisfaction is developed Brefild roth and gujarati translate measured by Parikh. Here t-test applied to check the significant difference of Occupational Stress and Job Satisfaction among Police and Teacher. Result revealed that significant difference Occupational Stress among Police and Teacher.There is significant difference in Job Satisfaction among Police and Teacher.
\end{abstract}

Keywords: Occupational Stress and Job Satisfaction

\section{Occupational Stress and Job Satisfaction}

Stress may be classified into eustress and distress. Eustress is positive or good stress, whereas distress is the stress reactions to those events or actions appraised as being negative. Stress-related disorders encompass a broad array of conditions, including psychological disorders (e.g., depression, anxiety, post-traumatic stress disorder) and other types of emotional strain (e.g.,dissatisfaction, fatigue,tension, etc.),maladaptive behaviors(e.g., aggression, substance abuse), and cognitive impairment (e.g., concentration and memory problems).In turn, these conditions may take the form of poor work Performance, higher absenteeism, less work productivity or even injury. Job stress is also associated with various biological reactions that may lead ultimately to compromised health, such as cardiovascular disease, or in extreme cases, even death. There are a total of 5 categories associated with occupational stress, Viz: 1. Factors unique to the job 2. Role in the organization 3. Career development 4. Interpersonal work relationships and 5. Organizational Structure/climat .These individual categories demonstrate that stress can occur specifically when a conflict stems from the job.

Job satisfaction is the general attitude that results from many attitudes in three areas, namely specific job factors, an individual's characteristics, and group relations outside the job (Blum \& Naylor, 1968). Nateson and Radhai (1990) administered a job satisfaction scale and a checklist of factors of job satisfaction to 50 executives and 50 supervisors in India. The supervisors indicated greater job satisfaction than the executives. The majority of executives had a low level of job satisfaction, whereas the majority of supervisors had a moderate level of job satisfaction. Salary, opportunity for advancements, job security, and working conditions were regarded by most of the executives as important factors of job satisfaction. Job security, working conditions, and coworkers' behavior were important factors of job satisfaction according to most of the supervisors. Singh and Pestonjee (1990) administered the employee inventory, the job involvement scale, and the psychological participation index to 250 officers and 250 clerks of a
Nationalized Bank in India in order to compare job Satisfaction with job status in the banking industry. Clerks indicated more job satisfaction than bank officers. The officers showed higher job involvement and more participation in decision making than Clerks.

Employee satisfaction is the terminology used to describe whether employees are happy, contended and fulfilling their desires and needs at work. Many measures support that employee satisfaction is a factor in employee motivation, employee goal achievement and positive employee morale in the work place. Basically Employee satisfaction is a measure of how happy workers are with their job and working environment.

Police Department is one of the important departments for societal wellbeing. Police have to work round the clock to keep public safe. Throughout the day they are doing a restless job. They don't have week end holiday and occasional holiday. In fact, on those days they have to work even harder in the name of bandhubast duty. Because of this they are not getting time to spend with their family members, which leads to frustration. Further, this frustration may manifest as depression and they will lose interest in their job. If we keenly observe, police men and of them will be having procrastinating attitude, impatience, and irritability etc which are the symptoms of Stress. And nowadays the suicide attempts are also on the rise in police department.

Teacher stress has been a concern in educational research for several decades. Americans are increasingly stressed. According to the Stress in America report from The American Psychological Association (2011) more than half of Americans would identify their level of stress as greater than 5 on a scale from 1 to 10 . Stress can be identified from many sources. One of the largest and most researched categories of stress in the United States is occupational stress, or stress arising from a person's career (Selye, 1956). With regard to occupational stress, multiple research studies have identified teaching as a high stress occupation (Bellingrath, Weigl, \& Kudielka, 2009; Kyriacou \& 


\section{International Journal of Science and Research (IJSR) \\ ISSN (Online): 2319-7064}

Index Copernicus Value (2013): 6.14 | Impact Factor (2015): 6.391

Sutcliffe, 1977; Pearson \& Moomaw, 2005; Russell, Altmaier, \&Van Velzen, 1987). Results from these studies conclude that between $19.9 \%$ and $30.7 \%$ of teachers reported feeling their job was either very stressful or extremely stressful (Kyriacou \& Sutcliffe, 1977, 1978, 1979). One specific survey of secondary teachers reported in more than $30 \%$ of respondents rated their occupational stress level as "extremely stressful" (Kyriacou \& Sutcliffe, 1977). With regard to agriculture teachers, a 2004a study by Roberts and Dyer found stress to be a top concern among agricultural educators.

Specific research has been conducted to identify the sources of teacher stress and the impact that it has on personal lives, job satisfaction, and ability to perform effectively in the classroom (Adams, 1999; Blasé, 1986; Borg \& Riding, 1991; Jennings \& Greenburg, 2009). Such research has shown that there are valid and significant outcomes when a teacher experiences occupational stress. Consequences of teacher stress include an increase in teacher burnout (Croom, 2003), negative impacts on teacher student relationships (Yoon, 2002) and substantial drop in attrition rates (Dinham, 1992; Sinclair \& Ryan, 1987). While the topic of teacher stress has been widely studied (Jenkins \& Calhoun, 1991; Kyriacou \& Sutcliffe, 1977, 1979; Parkay, Greenwood, Olejnik, \& Proller, 1988), far less research has been conducted on the methods for coping with teacher stress. Lazarus (1966) explained the method by which stress occurs. Individuals encounter potential stressors, or events with the ability to illicit a physical, mental, or emotional response. Each person processes that event through a variety of tactics to minimize the impact of the potential stressor. The tactics used to reduce the actual amount of stress experienced by a potential stressor are referred to as coping mechanisms. After an individual has utilized coping mechanisms to process a potential stressor, the remaining impact of that event is considered stress (Folkman, Lazarus, Dunkel-Schetter, DeLongis, \& Gruen, 1986) A comprehensive search into the methods of coping employed by agricultural educators yielded few results, demonstrating that there has been little research completed on the subject. Early research indicates some correlation between coping methods used by agricultural educators and burnout scores (Newcomb, Betts, \& Cano, 1987), but fails to fully establish the frequency of multiple coping strategies.

Understanding the coping strategies employed by agriculture teachers allows for an in-depth look at how stressors are managed by agriculture teachers. This examination may allow further research into the ways that specific coping mechanisms can lessen the impact of potential stressors on teachers. It may also answer questions related to why agriculture teachers can experience similar potential stressors, and have differing levels of stress from the event.

\section{Review of Literature}

In the introductory paper the aim and scope of the present study has been discussed. This paper deals with the review of literature, which is an important aspect of any research. It helps to trace out the past trends in any particular branch of subject. The review of literature helps to identify the areas of research. There have been a lot of studies conducted to understand the relationship between occupational stress and job satisfaction both at national and international level. In this chapter various previous studies relating to stress management and job satisfaction have been reviewed and how the present study differs from them are also discussed in detail.

\section{1) Study Occupational Stress:}

Wu SY, Wang M Z, Li J, Zhang X F,(2006) conducted a “ study of the intervention measures for the occupational stress to the teachers in the primary and secondary school", Objective of the study was to study the status of the occupational stress and the work ability of the teache-rs in the primary and secondary schools, then to take some integrated intervention measures to reduce the occupational stress and improve their work ability, and evaluate the intervening efficacy. The levels of stressor and strain was measured with the occupation stress inventory revised edition (OSI-R) and the work ability was measured with the work ability index (WAI) for the teachers in nine primary and secondary schools in Sichuan Province, then health educations about occupational stress was taken for the teachers in the study group, the same test was carried out after one year for the teachers in the nine schools to evaluate the effect of interventional measures The study concluded that the intervention measure were efficient to reduce the occupational stress of teachers, strengthen their coping resource and improve their work ability.

Singh Anurag (2012)Occupational stress has become a great matter of concern among the IT Companies all over the world, which create lots of human resources problems like executives intension to leave the organization, it also create loss of talent as well as money of IT companies. The present Paper studies assess level of occupational stress among the executives in Indian multinationals IT companies the paper also studies level of occupational stress among the executives in foreign multinational IT companies.

Kohinoor Akhtar (2012) emphasized that the stress is mandatory according to modern school of thought but excessive targets and lack of motivational practices degenerates the engagement level of employee within the organization which causes less job satisfaction and leads to less organizational commitment. HRM policies play a major role in handling stress and healthy environment in organization and show that stress has a inverse relationship with psychological fitness which contribute to the total productivity and employability. This study is based on trend analysis of corporate stress and its relation with the psychological fitness of employees working in Information Technology Industry in Mumbai Region.

\section{2) Study job satisfaction}

Talma Rosenthal, et al., (2012) pointed out that the occupational stress, or job strain, resulting from a lack of balance between job demands and job control, is considered one of the frequent factors in the etiology of hypertension in modern society. Stress, with its multifactorial causes, is complex and difficult to analyze at the physiological and psychosocial levels. The possible relation between job strain and blood pressure levels has been extensively studied, but the literature is replete with conflicting results regarding the 


\section{International Journal of Science and Research (IJSR) \\ ISSN (Online): 2319-7064}

Index Copernicus Value (2013): 6.14 | Impact Factor (2015): 6.391

relationship between the two. Further analysis of this relationship, including the many facets of job strain, may lead to operative proposals at the individual and public health levels designed to reduce the effects on health and well-being. In this study, researchers reviewed the literature on the subject, discussing the various methodologies, confounding variables, and suggested approaches for a healthier work environment. Abdul Qayyum Chaudhry (2012)aims to find out the relationship between occupational stress and job satisfaction based on age, gender, nature of job, cadre, work experience of university teachers, and sector of university. The Pearson correlation indicates: no significant relationship found between job satisfaction and overall occupational stress; inverse relationship is found between the occupational stress and overall job satisfaction in faculty members of private universities; is no relationship between the occupational stress and overall job satisfaction in faculty members of public universities; no relationship between the occupational stress and overall job satisfaction in case of both male and female faculty members of universities; young age university teachers are more sensitive to the Occupational stress and job satisfaction; and no significant relationship is found between the occupational stress and overall job satisfaction in faculty members of universities across the nature of job; visiting, contract and permanent.

Anurag Singh, et al., (2012) pointed out occupational stress is a key problem before organizational leadership, in this study researchers tried to explore the relationship between occupational stress and leadership behavior of organizational managers and researchers found that most of behavioral researchers are believed that reason of occupational stress may be different but there is most important reason may in its leadership behavior. The findings reflect the leadership styles exhibited by the managers in organizations. It appears that the leadership style of the managers vary depending upon various factors like the situation, need of the subordinates personal attributes etc. few studies were available highlighting the impact of leadership style of superior on the level of stress of the subordinates. Though different studies on the variables of occupational stress among executives indicate that role overload, role ambiguity, role conflict, under participation,

\section{3) Research problem:}

"Occupational Stress and Job Satisfaction among Police and Teacher"

\section{4) Objectives:}

The main objectives of study were as under:

1. To measure the Occupational Stress among Police and Teacher.

2. To measure the Job Satisfaction among Police and Teacher.

\section{5) Null-Hypothesis:}

To related objectives of this study null-hypothesis were as under:

1. There is no significant difference in Occupational Stress among Police and Teacher.

2. There is no significant difference in Job Satisfaction among Police and Teacher.

\section{Method}

\section{Participants:}

According to the purpose of present study total 60 samples has been selected. There were 30 Police and 30 Teacher. They were taken as a sample from different area in Amreli district.

\section{Instruments:}

For this purpose the following test tool were considered with their reliability, validity and objectivity mentioned in their respective manuals. In present study two inventory used in research.

\section{1) Occupational Stress scale}

The scale was developed by psychologist A.K. Shrivastav \& Singh[1981]. Total 46 statements in this scale, parting in two part very 'positive' and 'negative'. In have positive sentence is $1,2,3,4,5,9,11,12,13,16,17,23,24,25,26,27,28$, $29,34,35,36,37,38,39,42,44,45$ and 46 it marks measurement is $5,4,3,2$, and 1 . In have negative sentence is $6,7,8,10,14,15,18,19,20,21,22,30,31,32,33,40,41$ and 43 it marks of measurement is1, 2, 3, 4 and 5.

\section{2) Job Satisfaction scale}

To check the Job Satisfaction scale was used. It is developed by Brefild roth and gujarati translate measured by Parikh [1985]. This scale has four type sentences which are divided two part in the scale: part Satisfaction and ill satisfaction sentence. The scale consisted of 18 items each was to be related on one point Job Satisfaction scale. The Job Satisfaction scale have 'Satisfaction' section sentence is $1,2,3,5,7,9,12,13,16$ and 18 , section 'ill satisfaction' sentence is $3,4,6,8,10,11,14,15$ and 17 .

\section{3) Procedure}

The testing was done on a group of Police and Teacher. The whole procedure of fill the inventory was explained to them fully and clearly. The instructions given on the questionnaire were explained to them. It was also made clear to them that their scores would be kept secret. It was cheeked that none of the subjects left any questions unanswered of that no subject encircled both the answers given against question.

\section{4) Research Design}

The aim of present research was to a study of Occupational Stress and Job Satisfaction among Police and Teacher. For these total 30 Police and Teacher were taken as a sample. Here to measure occupational stress scale by psychologist A.K. Shrivastav \&Singh[1981]. While the tools for Job Satisfaction is Brefild roth and gujarati translate measured by Parikh [1985]. To check the difference between groups, $\mathrm{t}-$ test was used. The result and discussion of study is as under.

\section{Result \&Discussion}

The mean objective of present study was to study of Occupational Stress and Job Satisfaction among Police and Teacher. In it statistical ' $t$ ' method was used. Result discussion of present study is as under. 


\section{International Journal of Science and Research (IJSR) \\ ISSN (Online): 2319-7064}

Index Copernicus Value (2013): 6.14 | Impact Factor (2015): 6.391

\section{Insert table-1}

According to table-1 the result obtained on the basic area of Occupational Stress reveals significant difference in among Police and Teacher.

In Occupational Stress received Police high mean score 135.60 as compare Teacher 124.10 (table-1). There has mean difference was 2.50. The ' $\mathrm{t}$ ' value was 2.02 (table-1) there was 0.05 level significant difference of Occupational Stress among Police and Teacher. So we can't that say first hypothesis was not accepted.

\section{Insert table-2}

According to table-2 the result obtained on the basic area of Job Satisfaction reveals not significant difference in among Police and Teacher.

In Job Satisfaction received Police high mean score 57.73 as compare Teacher 63.47(table-2). There has mean difference was 2.72. The ' $t$ ' value was 2.71 (table-2) there was 0.01 level significant. There was significant deference of Police and Teacher in Job Satisfaction. So we can't say that second hypothesis was not accepted.

\section{Conclusion}

There were significant differences in Occupational Stress among Police and Teacher. There were significant differences in Job Satisfaction among Police and Teacher.

\section{Limitation}

In the research work taken sample was not achieved with concentration on particular area. The study was restricted to only male Police and Teacher. There for other male in not affected with the result. The present research includes 60 samples. So generalization of the result might be unfelt here. No other mental except questionnaires had been adopted in the present research work for the collection of information. In sample selection this random method was followed. The present research in only a part of the study, thus generalization should not be consummated, the scientific in not approached in the selection of sample. The conclusions of the present research are significant so one aspect the limitation reveals that both Occupational Stress and Job Satisfaction among Police and Teacher aspect of a person's (women) personality, character and occupation. There for in this practical world all people are taken differently and act differently. So it is inevitably complicated task to determine the proportion of Occupational Stress and Job Satisfaction among Police and Teacher in person's character and occupation.

\section{Suggestion}

Endeavour can be executed to analyze move them 60 data of sample with efficacy to attain better results. For the accumulation of information, variegated methods except questionnaires can be adopted. Selection of sample can be accomplished with the intake of different people from different state and district to ascertain their Occupational
Stress and Job Satisfaction among Police and Teacher. To crown the research work, other method of selecting sample can be appropriated.

\section{References}

[1] Adams, E. (1999): "Vocational teacher stress and internal characteristics", Journal of Vocational and Technical Education, 16(1), 28-36.

[2] American Psychological Association (2011): "Stress in America Survey", Retrieved from http://www.apa.org/news/press/releases/stress/2011/fina 1-2011.pdf

[3] Abdul Qayyum Chaudhry[2012]:"Relationship between Occupational Stress and Job Satisfaction: The Case of Pakistani Universities", International Education Studies Vol. 5, No. 3; June 2012.

[4] Anurag Singh and Dr. Amit Kumar Singh[2012]: "Occupational Stress \& Leadership: A Critical Review" International Journal of Innovative Research in Commerce \& Management, Vol.3, No. 3, pp. 1-9, April, 2012.

[5] Bellingrath, S., Weigl, T., \& Kudielka, B. (2009): Chronic work stress and exhaustion is Associated with higher allostatic load in female school teachers. Stress, 12(1), 37-48.

[6] Blasé, J. (1986): “ A qualitative analysis of sources of teacher stress: Consequences for performance", American Educational Research Journal, 23(1), 13-40. doi: 10.3102/00028 -312023001013

[7] Borg, M., \& Riding, R.J. (1991): “ Occupational stress and satisfaction in teaching", British Educational Research Journal, 17(3), 263-271. doi: 10.1080/0141192910170306

[8] Blum, M.L., \& Naylor, J.G. (1968): "Industrial psychology: Its theoretical social foundation", New Delhi: CBS Publishers.

[9] Croom, D. B. (2003): "Teacher burnout in agricultural education", Journal of Agricultural Education, 44(2), 213. doi: 10.5032/jae.2003.02001

[10] Dinham, S. (1992):"Teacher induction: Implications for administrators", Practicing Administrator, 14(4), 30-33.

[11]Folkman, S., Lazarus, R. S., Dunkel-Schetter, C., DeLongis, A., \& Gruen, R. (1986): “ The dynamics of a stressful encounter: cognitive appraisal, coping, and encounter outcomes", Journal of Personality and Social Psychology, 50(5), 992-1003. doi: 10.1037/00223514.50.5.992

[12] Jenkins, S., \& Calhoun, J. (1991): "Teacher stress: issues and intervention", Psychology in the Schools, 28(1),60-

70.doi:10.1002/15206807(199101)28:1<60::aidpits2310 280110> 3.0.co;2-b

[13] Jennings, P., \& Greenburg, M. (2009): “ The prosocial classroom: teacher social and emotional competence in relation to student and classroom outcomes" Review of Educational Research, 79(1), 491-525. doi: 10.3102/0034654308325693.

[14] Lazarus, R. S.(1966): "Psychological stress and the coping process"New York,NY: McGraw Hill.

[15] Luhar Urmilaben M.[2015]:“A STUDY OF OCCUPATIONAL STRESS, JOB INVOLVEMENT AND JOB SATISFACTION OF PRIVATE AND 


\section{International Journal of Science and Research (IJSR) ISSN (Online): 2319-7064}

Index Copernicus Value (2013): 6.14 | Impact Factor (2015): 6.391

PUBLIC EMPLOYEES” M.PHIL.DISSERT-

ATION,Department of Psychology Saurashtra University Rajkot.

[16] Kohinoor Akhtar,[2012]“Occupational Stress And Psychological Fitness - Study Of Information Technology Sector In Mumbai Area" International Journal Of Management Research And Review, Jan 2012, Vol. 2/Issue 1, pp.61-73.

[17] Kyriacou, C., \& Sutcliffe, J. (1977): “ Teacher stress: A review", Educational Review, 29(4), 299-306. doi :10.1080/0013191770290407.

[18] Kyriacou, C., \& Sutcliffe, J. (1978): “Teacher stress: Prevalence, sources, and symptoms", British Journal of Educational Psychology, 48(2), 159-167. doi: 10.1111/j.2044-8279. 1978.tb02381.x

[19] Kyriacou, C., \& Sutcliffe, J. (1979). A note on teacher stress and locus of control. Journal of Occupational Psychology, 52(3), 227-228. doi: 10.1111/j.20448325.1979.tb00456.x

[20] Nateson, H., \& Radhai, K. (1990): "Extent of job satisfaction among executives and supervisors and the factors promoting job satisfaction", Journal of the Indian Academy of Applied Psychology, 16,49-52.

[21] Newcomb, L., Betts, S., \& Cano, J. (1987). Extent of burnout among teachers of vocational agriculture in Ohio. Journal of Agricultural Education,28(1),2634.doi:10.5032/jaatea.1987.01017

[22] Parkay, F., Greenwood, G., Olenjik, S., \& Proller, N. (1988): "A Study of the relationships among teacher efficacy, locus of control, and stress", Journal of Research \& Development in Education, 21(4), 13-22.

[23] Russell, D. W., Altmaier, E., \& Van Velzen, D. (1987): " Job-related stress, social support, and burnout among classroom teachers", Journal of Applied Psychology, 72(2), 269-274. doi: 10.1037/0021-9010.72.2.269

[24] Sanjay Srivastava Arun K. Sen[1995]: "Role Stress, Job Anxiety, Job Involvement, and Job Satisfaction Among Three Groups of Organizational Employees: A Factor Analytic Study, University of Delhi, India, INTERNATIONAL JOURNAL OF OCCUPATIONAL SAFETY AND ERGONOMICS 1995, VOL. 1, NO. 3, 252-261

[25] Sinclair, K. E., \& Ryan, G. (1987). Teacher anxiety, teacher effectiveness, and student anxiety. Teaching and Teacher Education, 3(3), 249-253. doi: 10.1016/0742 051X(87)90007-2

[26] Smt.Rashmi Hunnur, Dr.M.M.Bagali , Dr.S Sudarshan [2014] :'Workplace Stress -Causes of Work Place Stress in Police Department: A Proposal for Stress Free , IOSR Journal of Business and Management (IOSRJBM) ， e-ISSN: 2278-487X, p-ISSN: 2319-7668. Volume 16, Issue 3. Ver. I (Mar. 2014), PP 39-47. Workplace'http://www.iosrjournals.org/iosrjbm/papers/Vol16-issue3/Version-1/F016313947.pdf

[27] Singh Anurag, [2012]:“A comparative study of occupational stress: Indian multinational companies it executives vs foreign multinationals companies it executive", Asian Journal of Research in Social Sciences and Humanities, 2011, Vol. : 1,Issue : 4, pp. 21-43.

[28] Singh, S., \& Pestonjee, D.M. (1990): "Job satisfaction, job involvement and participation amongst different categories of bank employees", Journal of Indian Academy of Applied Psychology, 16, 37-43.

[29] Selye, H. (1956): The stress of life. New York, NY: McGraw-Hill.

[30] Talma Rosenthal and Ariela Alter,[2012]: "Occupational stress and hypertension", Journal of the American Society of Hypertension, Vol. 6, issue 1, $\mathrm{pp} / 2-22,2012$.

[31] Yoon, J. S. (2002): "Teacher characteristics as predictors of teacher-student relationships: Stress, negative affect, and self-efficacy", Social Behavior and Personality: An International Journal, 30 (5), 485-493.

Online Website

[32] 'CHAPTER - IIREVIEW OF LITERATURE' http://shodhganga.inflibnet.ac.in/bitstream/10603/40221/4/chapter.2.pdf

[33] '41CHAPTER-II REVIEW OF LITERATURE' http://shodhganga.inflibnet.ac.in/bitstream/10603/27400/8/08 chapter\%202.pdf

\section{Result Table}

Table 1: Showing means, S.D. and t-value of Occupational Stress.

\begin{tabular}{|c|c|c|c|c|c|}
\hline S. No. & Sample Groups & $\mathrm{N}$ & Mean & SD & T \\
\hline 1 & police & 30 & 135.6 & 14.92 & \\
\hline 2 & teacher & 30 & 124.1 & 20.32 & $2.50^{* *}$ \\
\hline
\end{tabular}

$* \mathrm{P}<0.05=2.02$

$* * \mathrm{P}<0.01=2.71$

Significant level $=0.01$ level Significant

Table 2: Showing means, S.D. and t-value of Job Satisfaction.

\begin{tabular}{|c|c|c|c|c|c|}
\hline Sr.No. & Sample Groups & $\mathrm{N}$ & Mean & SD & T \\
\hline 1 & police & 30 & 57.73 & 8.43 & \\
\hline 2 & teacher & 30 & 63.47 & 7.88 & $2.72^{* *}$ \\
\hline
\end{tabular}

$* \mathrm{P}<0.05=2.02$

$* * \mathrm{P}<0.01=2.71$

Significant level $=0.01$ level Significant 